\title{
In situ DNA TRANSFER TO CHICKEN EMBRYOS BY BIOLISTICS
}

\author{
Luciana A. Ribeiro', João L. Azevedo ${ }^{2}$,Francisco J.L. Aragão ${ }^{3}$, Elibio L. Rech ${ }^{3}$, \\ Gilberto S. Schmidt ${ }^{4}$ and Luiz L. Coutinho ${ }^{1}$
}

\begin{abstract}
Fertilized chicken eggs were bombarded with a biolistic device. Transient expression of the lacZ gene under the control of a human cytomegalovirus (CMV) promoter was assessed after in situ gene transfer using this approach. The influence of different pressures, vacuum levels and particles was tested. Survival rate improved as particle velocity decreased, but resulted in lower levels of expression. The best survival and expression were obtained with gold particles, a helium gas pressure of $600 \mathrm{psi}$ and a vacuum of $600 \mathrm{mmHg}$. Under these conditions, all bombarded embryos showed $\beta$-galactosidase activity, indicating that this was an effective method for transformation of chicken embryos.
\end{abstract}

\section{INTRODUCTION}

DNA transfer methods have led to significant advances in exogenous gene expression. Transgenic animals have been used as models for studying gene functions and for producing very marketable proteins.

Microinjection has been the most studied form of transgenic production in mammals, but is considerably more difficult to apply to poultry (Li et al., 1995). The main difficulty with the latter is that at the time of ovoposition the embryo has already more than 60,000 cells. One of the strategies used to solve this problem is pronucleus transformation in recently fertilized eggs.

Other techniques used successfully in poultry include cell transfection with retroviral vectors, lipofection in ovo, electroporation and biolistics (Muramatsu et al., 1997). When stable gene expression and transgenic offspring are desired, stem cell transfection using retroviral vectors is the most convenient and successful technique (Petitte et al., 1990). The most commonly used stem cells are blastodermal or primordial germ cells. When blastodermal cells are used, they are transfected in ovo with retroviruses. The resulting chimaeric embryos contain foreign genes in their germ line and generate transgenic offspring (Bosselman et al., 1989). When primordial germ cells are used, foreign DNA is introduced into previously isolated cells using defective retroviruses. These cells are then transferred to recipient embryos to populate the gonads. Chimaeric embryos will produce transgenic offspring (Vick et al., 1993).

There are, however, two problems with these methods. First, embryo manipulation is very difficult, which increases the death rate, especially during the initial stages of incubation. Second, it is very difficult to predict the

\footnotetext{
${ }^{1}$ Departamento de Zootecnia, Escola Superior de Agricultura Luiz de Queiroz, ESALQ/USP, Av. Pádua Dias, 11, Caixa Postal 9, 13418-900 Piracicaba, SP, Brasil. Send correspondence to L.L.C.

${ }^{2}$ Departamento de Genética, ESALQ/USP, Piracicaba, SP, Brasil.

${ }^{3}$ Embrapa/Cenargen, SAIN Parque Rural, Brasília, DF, Brasil.

${ }^{4}$ Embrapa Suínos e Aves, Concórdia, SC, Brasil.
}

potential fate of the blastodermal cells and, consequently, to predict whether these cells will populate the gonads (Petitte et al., 1990).

When transient expression is desired, in ovo lipofection, electroporation and biolistics have been used to transfect chicken embryos (Muramatsu et al., 1997). Biolistics have been used in a variety of animal tissues (Yang et al., 1990; Williams et al., 1991; Klein and FitzpatrickMcElligott, 1993; Rech et al., 1996).

This report describes the development and optimization of a method for the introduction and transient expression of genes in chicken embryos bombarded in situ.

\section{MATERIAL AND METHODS}

\section{Chicken embryos}

Fertilized chicken eggs were incubated at $38^{\circ} \mathrm{C}$ for $30 \mathrm{~h}$. In developmental stage 10 embryos (Hamburger and Hamilton, 1951) were bombarded in situ. A small hole (10-15 mm) was made on the rounded end of the egg to expose the embryo to bombardment. After bombardment, the shells were sealed with PVC film and the eggs then incubated for an additional $24 \mathrm{~h}$ at $38^{\circ} \mathrm{C}$.

\section{Plasmid}

The plasmid used was $\mathrm{pCMV} \beta$, which contains the lacZ gene from Escherichia coli under control of the human cytomegalovirus (CMV) immediate early gene promoter/enhancer (CLONTECH, Palo Alto, CA, USA). The protocol for plasmid precipitation into gold or tungsten particles was described by Aragão et al. (1996).

\section{Bombardment}

A high pressure helium gas apparatus, built in our laboratory based on the design described by Sanford $\mathrm{et}$ al. (1991), was used to bombard the embryos. The distance from the rupture and carrier membranes was $0.6 \mathrm{~cm}$. The 
carrier membrane flying distance to the stopping screen was $2.0 \mathrm{~cm}$ and the DNA-coated microparticle flying distance to the embryo was $11.0 \mathrm{~cm}$.

Three types of microparticles were tested for plasmid precipitation: gold with a diameter of 1.5-3.0 $\mu \mathrm{m}$ (Aldrich No. 32.658-5), and tungsten with diameters of 0.2 $\mu \mathrm{m}$ (M5, Sylvania Inc.) and $1.2 \mu \mathrm{m}$ (M10, Sylvania Inc.). The bombardment conditions were as follows: a $600-\mathrm{mmHg}$ vacuum to test 400-, 500- and 600-psi helium gas pressures and a $400-\mathrm{mmHg}$ vacuum to test 800-, 900-, 1000- and 1500psi helium gas pressures. M5 tungsten particles $(0.2 \mu \mathrm{m})$ were used to test 600-, 900- and 1200-psi pressures, and M10 tungsten particles $(1.2 \mu \mathrm{m})$ were used for $600-$ and 900-psi pressures, with a $600-\mathrm{mmHg}$ vacuum in all cases.

A laser pen indicated the center of the particle dispersion zone (dead zone). Two positions for embryo placement (center of the dead zone and $1 \mathrm{~cm}$ from the center) were tested. Embryo targeting with a laser pen was used only in the tungsten particle experiments.

\section{$\beta$-Galactosidase activity}

$\beta$-Galactosidase ( $\beta$-gal) activity was detected by a histochemical assay. Twenty-four hours after bombardment, embryos were fixed in a $4 \%$ paraformaldehyde solution for $5 \mathrm{~min}$ at $4^{\circ} \mathrm{C}$, followed by staining for $4 \mathrm{~h}$ at $37^{\circ} \mathrm{C}$ with a chromogenic substrate containing $100 \mathrm{mM}$ sodium phosphate, $1.3 \mathrm{mM} \mathrm{MgCl}_{2}, 3 \mathrm{mM} \mathrm{K}_{4} \mathrm{Fe}(\mathrm{CN})_{6}, 3$ $\mathrm{mM} \mathrm{K}_{3} \mathrm{Fe}(\mathrm{CN})_{6}$ and $1 \mathrm{mg} \mathrm{X}$-gal (5-bromo-4-chloro-3indolyl- $\beta$-D-galactopyranoside)/ml. $\beta$-Galactosidase expression was detected histochemically by the hydrolysis of $\mathrm{X}$ gal to produce insoluble indigo. The resulting blue color indicated the localization of $\beta$-gal activity in transformed embryos. Transformation was verified by the absence or presence of blue points (expression units) representing gene expression in a cell or group of cells. All embryos with blue points were considered in the analyses, independently of the number of units expressed. Embryos that showed $\beta$-gal activity were classified into two expression categories: 1 ) expression in embryo body and extra-embryonic tissue (total expression), 2) expression in embryo body.
Non-bombarded embryos were used as negative controls and did not show any staining. Embryo survival, defined as the presence of heartbeat, was recorded $24 \mathrm{~h}$ after bombardment.

\section{RESULTS AND DISCUSSION}

Each species or cell type requires different conditions for DNA transfer (Gendreau et al., 1995; Zelenin et al., 1991; Williams et al., 1991), and we have optimized these parameters for chicken embryos.

We initially tested a vacuum of $600 \mathrm{mmHg}$, gold particles and pressures of 400-600 psi. Thirty-six embryos were bombarded: 10 with 400 psi, 10 with 500 psi and 16 with $600 \mathrm{psi}$ (Table I). The survival rate was approximately $30 \%$ for the three pressures. Approximately $53 \%$ of the embryos expressed $\beta$-galactosidase in their body cells, with $19.4 \%$ of these showing more than 100 expression units (blue points). The number of punctured yolks was close to $30 \%$ for the three conditions.

To reduce embryo damage and increase the survival rate, we repeated the experiments at a lower vacuum (400 $\mathrm{mmHg}$ instead of $600 \mathrm{mmHg}$ ). In this case, air resistance was greater and the particle velocity was reduced. Forty-eight embryos were bombarded: 14 with 600 psi, 11 with 800 psi, 6 with 900 psi, 11 with 1000 psi and 6 with $1500 \mathrm{psi}$ (Table II). Higher helium pressures were not tested since several egg yolks ruptured at 1500 psi. Embryo survival was greater than that achieved in the previous experiment, reaching an average of $56 \%$. A pressure of 1500 psi was harmful to the embryos with only one out of six embryos surviving bombardment under this condition. Overall, the efficiency of transformation was low; only one embryo with 20 blue points in the body cells was obtained at a pressure of 1500 psi. At the remaining pressures, expression in extra-embryonic tissue cells was seen in $28.6 \%$ of the embryos bombarded. Thus, our attempt to increase survival by reducing the vacuum was offset by a reduction in expression. To overcome the lower efficiency of transformation, higher pressures were tested, but these reduced embryo survival.

Table I - Effect of helium pressure on $\beta$-gal expression in embryos bombarded with gold particles at a vacuum of $600 \mathrm{mmHg}$.

\begin{tabular}{|lccccc|}
\hline $\begin{array}{l}\text { Helium } \\
\text { (psi) }\end{array}$ & $\mathrm{N}$ & \multicolumn{2}{c|}{$\begin{array}{c}\text { Efficiency of transformation }(\%) \\
\text { Embryos with }\end{array}$} & $\begin{array}{c}\text { Ruptured yolks } \\
(\%)\end{array}$ & $\begin{array}{c}\text { Survival } \\
(\%)\end{array}$ \\
\cline { 3 - 5 } & & $\begin{array}{c}\text { Embryos with } \\
\text { total expression }\end{array}$ & expression in body cells & & \\
\hline 400 & 10 & $80.0(8 / 10)^{2}$ & $50.0(5 / 10)^{3}$ & $20.0(2 / 10)^{4}$ & $40.0(4 / 10)^{5}$ \\
500 & 10 & $60.0(6 / 10)$ & $50.0(5 / 10)$ & $40.0(4 / 10)$ & $20.0(2 / 10)$ \\
600 & 16 & $68.7(11 / 16)$ & $56.2(9 / 16)$ & $31.2(5 / 16)$ & $31.2(5 / 16)$ \\
\hline
\end{tabular}

${ }^{1}$ Embryos with $\beta$-gal expression in body cells and extra-embryonic tissue. ${ }^{2}$ No. of embryos expressing $\beta$ gal/total number of embryos bombarded. ${ }^{3}$ No. of embryos expressing $\beta$-gal in body cells/total number of embryos bombarded. ${ }^{4}$ No. of yolks ruptured at the moment of bombardment/total number of eggs bombarded. ${ }^{5}$ No. of embryos with heartbeat $24 \mathrm{~h}$ after bombardment/total number of embryos bombarded. 
Table II - Effect of helium pressure on $\beta$-gal expression in embryos bombarded with gold particles at a vacuum of $400 \mathrm{mmHg}$.

\begin{tabular}{|c|c|c|c|c|c|}
\hline \multirow{2}{*}{$\begin{array}{l}\text { Helium } \\
\text { (psi) }\end{array}$} & \multirow[t]{2}{*}{$\mathrm{N}$} & \multicolumn{2}{|c|}{ Efficiency of transformation (\%) } & \multirow{2}{*}{$\begin{array}{l}\text { Ruptured yolks } \\
(\%)\end{array}$} & \multirow{2}{*}{$\begin{array}{r}\text { Survival } \\
(\%)\end{array}$} \\
\hline & & $\begin{array}{l}\text { Embryos with } \\
\text { total expression }^{1}\end{array}$ & $\begin{array}{c}\text { Embryos with } \\
\text { expression in body cells }\end{array}$ & & \\
\hline 600 & 14 & $21.4(3 / 14)^{2}$ & - & - & $78.6(11 / 14)$ \\
\hline 800 & 11 & $27.3(3 / 11)$ & - & $27.3(3 / 11)^{4}$ & $45.4(5 / 11)$ \\
\hline 900 & 6 & $50.0(3 / 6)$ & - & - & $33.3(2 / 6)$ \\
\hline 1000 & 11 & $27.3(3 / 11)$ & - & $18.2(2 / 11)$ & $72.7(8 / 11)$ \\
\hline 1500 & 6 & $66.7(4 / 6)$ & $16.7(1 / 6)^{3}$ & $33.3(2 / 6)$ & $16.7(1 / 6)$ \\
\hline
\end{tabular}

${ }^{1}$ Embryos with $\beta$-gal expression in body cells and extra-embryonic tissue. ${ }^{2}$ No. of embryos expressing $\beta$ gal/total number of embryos bombarded. ${ }^{3}$ No. of embryos expressing $\beta$-gal in body cells/total number of embryos bombarded. ${ }^{4} \mathrm{No}$. of yolks ruptured at the moment of bombardment/total number of eggs bombarded. ${ }^{5}$ No. of embryos with heartbeat $24 \mathrm{~h}$ after bombardment/total number of embryos bombarded.

Table III - Effect of helium pressure on $\beta$-gal expression in embryos bombarded with M5 tungsten particles at a vacuum of $600 \mathrm{mmHg}$.

\begin{tabular}{|c|c|c|c|c|c|}
\hline \multirow{2}{*}{$\begin{array}{l}\text { Helium } \\
\text { (psi) }\end{array}$} & \multirow[t]{2}{*}{$\mathrm{N}$} & \multicolumn{2}{|c|}{ Efficiency of transformation (\%) } & \multirow{2}{*}{$\begin{array}{l}\text { Ruptured yolks } \\
(\%)\end{array}$} & \multirow{2}{*}{$\begin{array}{l}\text { Survival } \\
(\%)\end{array}$} \\
\hline & & $\begin{array}{l}\text { Embryos with } \\
\text { total expression }\end{array}$ & $\begin{array}{l}\text { Embryos with } \\
\text { expression in body cells }\end{array}$ & & \\
\hline 600 & 9 & $88.9(8 / 9)^{2}$ & $33.3(3 / 9)^{3}$ & $11.1(1 / 9)^{4}$ & $66.7(6 / 9)^{5}$ \\
\hline 900 & 15 & $60.0(9 / 15)$ & $13.3(2 / 15)$ & $33.3(5 / 15)$ & $46.7(7 / 15)$ \\
\hline 1200 & 9 & $22.2(2 / 9)$ & - & $66.7(6 / 9)$ & $11.1(1 / 9)$ \\
\hline
\end{tabular}

${ }^{1}$ Embryos with $\beta$-gal expression in body cells and extra-embryonic tissue. ${ }^{2}$ No. of embryos expressing $\beta$ gal/total number of embryos bombarded. ${ }^{3}$ No. of embryos expressing $\beta$-gal in body cells/total number of embryos bombarded. ${ }^{4} \mathrm{No}$. of yolks ruptured at the moment of bombardment/total number of eggs bombarded. ${ }^{5}$ No. of embryos with heartbeat $24 \mathrm{~h}$ after bombardment/total number of embryos bombarded.
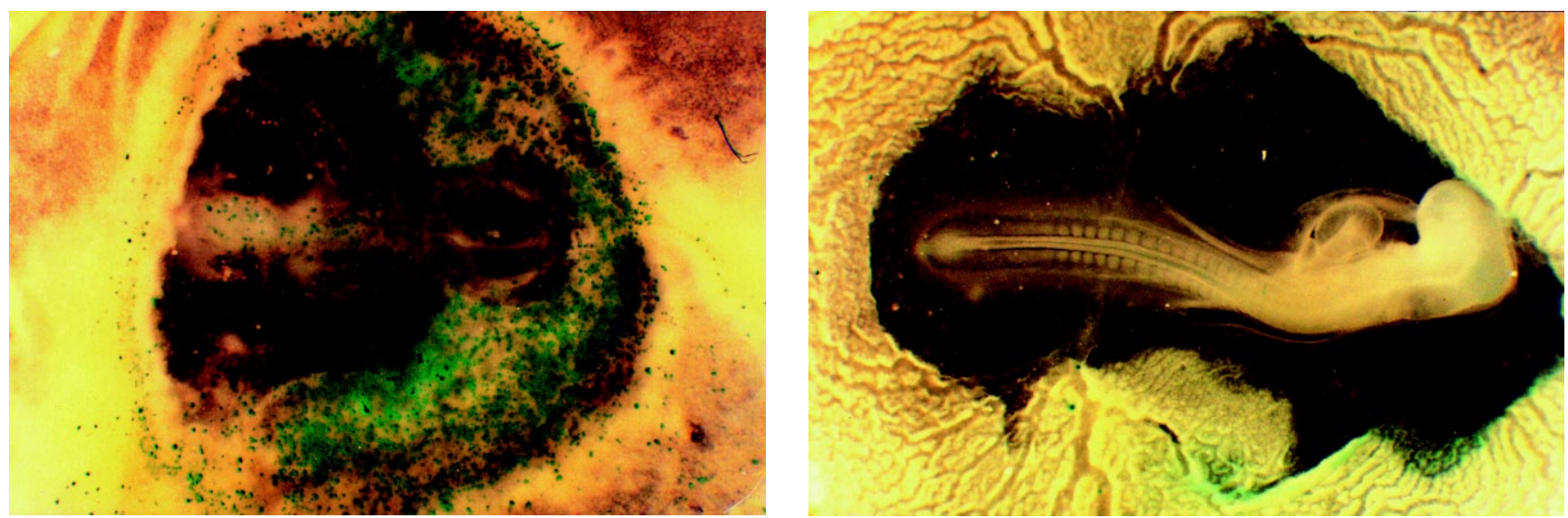

Figure 1 - Embryos bombarded with gold particles at $600 \mathrm{psi}$ helium and a vacuum of $600 \mathrm{mmHg}$ (A) or $400 \mathrm{mmHg}$ (B). Blue points indicate $\beta$-galactosidase expression.

Figure 1 compares embryos bombarded at different vacuum levels using gold particles and helium at 600 psi. The embryo bombarded under a vacuum of $600 \mathrm{mmHg}$ had a greater number of expression units than that bombarded under $400 \mathrm{mmHg}$, but showed abnormal tissue development.

In an attempt to improve embryo survival, smaller tungsten particles were tested since the particle material, size and form are known to influence the efficiency of trans- formation (Klein et al., 1992). Table III shows the results with $0.2-\mu \mathrm{m}$ tungsten particles at $600 \mathrm{mmHg}$ and pressures of 600, 900 and 1200 psi. Higher pressures were not used because of the increased frequency of ruptured yolks $(66.7 \%)$. The average survival rate with the three pressures was $42.4 \%$. A pressure of 1200 psi produced the greatest decrease in survival rate. Only one out of nine embryos bombarded survived. The number of expression 
Table IV - Effect of helium pressure on $\beta$-gal expression in embryos placed $1 \mathrm{~cm}$ from the dead zone, using M10 tungsten particles at a vacuum of $600 \mathrm{mmHg}$.

\begin{tabular}{|c|c|c|c|c|c|}
\hline \multirow{2}{*}{$\begin{array}{l}\text { Helium } \\
\text { (psi) }\end{array}$} & \multirow[t]{2}{*}{$\mathrm{N}$} & \multicolumn{2}{|c|}{ Efficiency of transformation (\%) } & \multirow{2}{*}{$\begin{array}{l}\text { Ruptured yolks } \\
(\%)\end{array}$} & \multirow{2}{*}{$\begin{array}{l}\text { Survival } \\
(\%)\end{array}$} \\
\hline & & $\begin{array}{l}\text { Embryos with } \\
\text { total expression }{ }^{1}\end{array}$ & $\begin{array}{l}\text { Embryos with } \\
\text { expression in body cells }\end{array}$ & & \\
\hline 600 & 6 & $66.7(4 / 6)^{2}$ & $16.7(1 / 6)^{3}$ & $33.3(2 / 6)^{4}$ & $33.3(2 / 6)^{5}$ \\
\hline 900 & 12 & $41.7(5 / 12)$ & $25.0(3 / 12)$ & $58.3(7 / 12)$ & $16.7(2 / 12)$ \\
\hline
\end{tabular}

${ }^{1}$ Embryos with $\beta$-gal expression in body cells and extra-embryonic tissue. ${ }^{2}$ No. of embryos expressing $\beta$ gal/total number of embryos bombarded. ${ }^{3}$ No. of embryos expressing $\beta$-gal in body cells/total number of embryos bombarded. ${ }^{4}$ No. of yolks ruptured at the moment of bombardment/total number of eggs bombarded. ${ }^{5}$ No. of embryos with heartbeat $24 \mathrm{~h}$ after bombardment/total number of embryos bombarded.
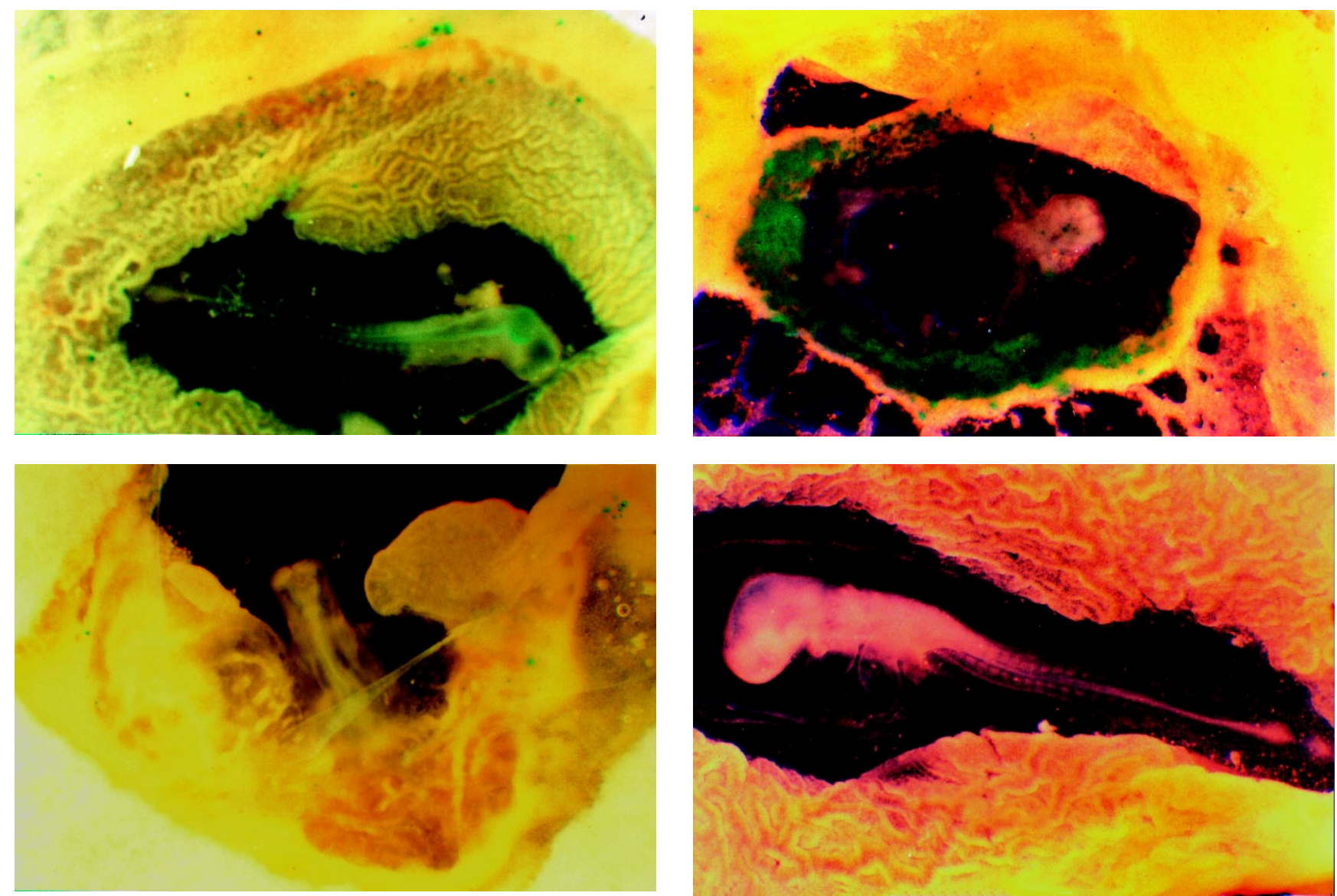

Figure 2 - Embryos bombarded with $0.2 \mu \mathrm{m}$ (A) and $1.2 \mu \mathrm{m}$ (B and C) tungsten particles at a helium pressure of $600 \mathrm{psi}$ and a vacuum of $600 \mathrm{mmHg}$. In C, the embryo was positioned $1 \mathrm{~cm}$ from the center of the dispersion zone while in $\mathrm{B}$ the embryo was placed under the center of the dispersion zone. D represents an embryo that was not bombarded.

units was low at all pressures tested and no embryo presented more than 10 expression units in the body cells.

In view of the continued low efficiency of transformation, another experiment was conducted using larger tungsten particles $(1.2 \mu \mathrm{m})$. Our rationale was that the reduced mass of the $0.2-\mu \mathrm{m}$ particle did not attain a velocity fast enough to penetrate the cells. Six embryos were bombarded with $600 \mathrm{psi}$ helium at a vacuum of $600 \mathrm{mmHg}$. A laser targeting system was adopted to indicate the center of the particle dispersion zone. The embryos were positioned under the red point generated by the laser pen, i.e., directly in the center of the dispersion zone. The efficiency of transformation was $100 \%$. All six embryos bombarded expressed $\beta$-gal in body cells. Nevertheless, the number of blue points was not very high, with only $50 \%$ of the embryos presenting more than 100 expression units. Survival rate was low, with only one embryo (16.7\%) surviving bombardment. The normal development of tissues and organs 
was severely affected. These results indicated that placing embryos directly under the dispersion zone should be avoided.

In a final set of experiments, embryos were positioned $1 \mathrm{~cm}$ from the center of the dispersion zone. Eighteen embryos were bombarded under a $600-\mathrm{mmHg}$ vacuum: 6 at 600 psi and 12 at 900 psi (Table IV). The survival rates were 33.3 and $16.6 \%$ in embryos bombarded with $600 \mathrm{psi}$ and $900 \mathrm{psi}$, respectively. At a pressure of 900 psi, $58.3 \%$ of the yolks burst on impact. The efficiency of transformation was $66.7 \%$ for embryos bombarded with 600 psi and $41.7 \%$ for those bombarded with 900 psi.

Figure 2 shows that embryos bombarded with 0.2 $\mu \mathrm{m}$ tungsten had fewer expression units compared to those bombarded with larger particles $(1.2 \mu \mathrm{m})$.

The position of the embryo relative to the dispersion zone was an important parameter in this experiments, since embryos placed in the center of the dispersion zone suffered serious tissue damage. Embryos bombarded with larger particles and placed $1 \mathrm{~cm}$ from the center of the dispersion zone showed a normal tissue development and an intermediate number of expression units compared to other conditions of bombardment.

In situ DNA transfer to chicken embryos was relatively successful. The CMV promoter used produced strong expression in several regions of the embryo and the reporter gene $l a c Z$ was easily detected. An efficiency of transformation of $68 \%$ and a $31.2 \%$ survival rate were obtained with gold particles, a $600-\mathrm{mmHg}$ vacuum and a helium pressure of 600 psi. All efforts to improve the level of transformation using higher helium pressures or vacuums resulted in more expression but a lower survival rate. The use of smaller particles to reduce embryo damage was unsuccessful because it resulted in a lower efficiency of transformation.

Previous reports have shown that biolistics can be used to transfer genes to chickens in ovo (Li et al., 1995; Muramatsu et al., 1997). Li et al. (1995) transformed primordial chicken embryo cells using an adapted surgical syringe and were able to detect the transgene in $20 \%$ of the positive male offspring. Muramatsu et al. (1997) used tungsten particles and 285 psi nitrogen to obtain a $45.8 \%$ efficiency of transformation and $42.9 \%$ survival rate. However, the number and intensity of expression units were low. Under our conditions, greater efficiency of transformation and expression levels were obtained. The high helium pressure used in our work could account for the difference between our results and those of other studies.

\section{ACKNOWLEDGMENTS}

We thank Vera Maria Quecini (ESALQ/USP) for her help with the biolistic experiments. Research supported by grants from FAPESP (Fundação de Amparo à Pesquisa do Estado de São Paulo) and EMBRAPA-CNPSA (Empresa Brasileira de Pequisa Agropecuária - Suínos e Aves). Publication supported by FAPESP.

\section{RESUMO}

Ovos fertilizados de galinha foram bombardeados através da técnica de biobalística. A expressão transiente do gene $l a c Z$, sob o controle do promotor humano citomegalovírus, foi verificada após a transferência in situ. Diferentes níveis de pressão de gás hélio, vácuo e tipos de partículas foram testados. A taxa de sobrevivência aumentou à medida que a velocidade das partículas diminuíram, entretanto, o nível de expressão foi menor. Os melhores resultados, combinando taxa de sobrevivência e expressão, foram obtidos com partículas de ouro, 600 libras por polegada ao quadrado de hélio e $600 \mathrm{mmHg}$ de vácuo. Nestas condições, todos os embriões bombardeados apresentaram atividade da $\beta$-galactosidase, indicando que esta técnica é eficiente para a transformação de embriões de galinhas.

\section{REFERENCES}

Aragão, F.J.L., Barros, L.M.G., Brasileiro, A.C.M., Ribeiro, S.G., Smith, F.D., Sanford, J.C., Faria, J.C. and Rech, E.L. (1996). Inheritance of foreign genes in transgenic bean (Phaseolus vulgaris L.) co-transformed via particle bombardment. Theor. App. Genet. 93: 142-150.

Bosselman, R.A., Hsu, R.Y., Boggs, T., Hu, S., Bruszewski, J., Nicholson, M., Schulz, J.A., Semon, K.M., Rushell, W. and Stewart, R.G. (1989). Germ line transmission of exogenous genes in the chicken. Science 243: 533-535.

Gendreau, S., Lardans, V., Cadoret, J.P. and Mialhe, E. (1995). Transient expression of a luciferase reporter gene after ballistic introduction into Artemia franciscana (Crustacea) embryos. Aquaculture 133: 199-205.

Hamburger, V. and Hamilton, H.L. (1951). A series of normal stages in the development of the chicken embryo. J. Morphol. 88: 49-92.

Klein, T.M. and Fitzpatrick-McElligott, S. (1993). Particle bombardment: a universal approach for gene transfer to cells and tissues. Curr. Opin. Biotechnol. 4: 583-590.

Klein, T.M., Arentzen, R., Lewis, P.A. and Fitzpatrick-McElligott, S. (1992). Transformation of microbes, plants and animals by particle bombardment. Biotechnology 10: 286-291.

Li, Y., Behnam, J. and Simkiss, K. (1995). Ballistic transfection of avian primordial germ cell in ovo. Transgenic Res. 4: 26-29.

Muramatsu, T., Mizutani, Y., Ohmori, Y. and Okumura, J. (1997). Comparison of three nonviral transfection methods for foreign gene expression in early chicken embryos in ovo. Biochem. Biophys. Res. Commun. 230: 376-380.

Petitte, J.N., Clark, M.E., Liu, G. and Gibbins, A.M.V. (1990). Production of somatic and germ line chimeras in the chicken by transfer of early blastodermal cells. Development 108: 185-189.

Rech, E.L., De Bem, A.R. and Aragão, F.J.L. (1996). Biolistic mediated gene expression in cattle tissues in vivo. Braz. J. Med. Biol. Res. 29: 1265-1267.

Sanford, J.C., Devit, M.J., Russell, J.A., Smith, F.D., Harpending, P.R., Roy, M.K. and Johnston, S.A. (1991). An improved, helium-driven biolistic device. Technique 3: 3-16.

Vick, L., Li, Y. and Simkiss, K. (1993). Transgenic birds from transformed primordial germ cells. Proc. Roy. Soc. Lond. B Biol. Sci. 251: 179-182.

Williams, R.S., Johnston, S.A., Riedy, M., DeVit, M.J., McElligott, S.G. and Sanford, J.C. (1991). Introduction of foreign genes into tissues of living mice by DNA-coated microprojectiles. Proc. Natl. Acad. Sci. USA 88: 2726-2730.

Yang, N.-S., Burkholder, J., Roberts, B., Martinell, B. and McCabe, D. (1990). In vivo and in vitro gene transfer to mammalian somatic cells by particle bombardment. Proc. Natl. Acad. Sci. USA 87: 9568-9572.

Zelenin, A.V., Alimov, A.A., Barmintzev, V.A., Beniumov, A.O., Zelenina, I.A., Krasnov, A.M. and Kolesnikov, V.A. (1991). The delivery of foreign genes into fertilized fish eggs using high-velocity microprojectiles. FEBS Lett. 287: 118-120.

(Received September 9, 1998) 
